\title{
Analysis on the Formation of Physical Space in Traditional Villages
}

\section{J. FENG}

\author{
School of Architecture Southeast University, Nanjing, Jiangsu, China
}

\begin{abstract}
By taking Jishan Village from Yong'an City of Fujian central mountainous area as the study carrier, this paper is to analyze the formation of physical space in villages from three aspects, namely, the architectural space, street space and overall space. As a part of traditional village study, the formation of physical space is definitely the basis of study on villages. Therefore, this paper is with certain theoretical values and practical significance.
\end{abstract}

KEYWORD: Traditional Villages; Jishan Village; Physical space; Formation

Formation generally refers to the manifestation and inherent structural features corresponding to certain physical space. The formation of settlement is with multiple complex connotations as well as richer meanings, which includes the gathering life style, spatial characteristics of the settlement and social structural features[1]. Settlement space is seen as an external representation of the ancient rationalistic thought and space concept, whose space formation has always been a focus by the building circle.

\section{CONSTITUTION OF VILLAGE SPACE}

Compared to urban settlements, the overall space formation of rural settlements is more single, which is generally constituted by houses and street space. The formation of physical space in villages discussed by this paper will been explained via three aspects, that is, the architectural space, street space and overall space of villages. The street space, as the structural texture, will be further elaborated by hierarchy on the basis of three spaces named transportation, water system and node.

\section{CASE ANALYSIS}

Located in the southwest of the urban area of Yong'an City in Fujian central mountainous area, Jishan village is $5 \mathrm{~km}$ always from the downtown and the family name of people in the village is only Liu. Built in the fifteenth year of Jiajing Emperor in

Ming Dynasty (in 1536), the village has had a history of over 470 years.
In general, settlements develop along with the time, the structure of which could gradually appear in the growth and substitution process. "At first, it is very vulgar, ... When it reaches some certain period, such natural layout will receive a kind of selfconsciousness[2]."The development and substitution of physical space in Jishan Village has roughly gone through the stages of settlement, development, peak and decline. In the early period of the Republic of China, Jishan Village reached its most prosperous time when the village construction became greatly improved. At that period, the overall spatial form, traditional building form and street system of the village have all formed a certain system with the basic fixation of mechanism and scale.

\subsection{Spatial form of buildings}

According to historical records, the space of houses in Jishan Village in the Ming Dynasty was mostly small with small standard width, the height of which was usually no more than 4 meters (such as the ancestral house of the Liu family). In the years when Emperor Kangxi was in power in Qing Dynasty, partial families of the Liu became well developed, plus the peak of the local building technique, the house space became also larger with the height even reached 5 meters. For example, there are 156 rooms for the Caipai house, which looks as huge as rafts and earns the name of "The Largest House in Fujian".

The construction space of traditional Jishan Village can generally be divided into two categories: one is the "Room-wing type" three-section courtyard and the other is the "Room-building type" courtyard. 
"Room-wing type" three-section courtyard is mainly constituted by principal rooms, left and right wing rooms, garth and the front yard, which is in the symmetric figure by taking the ancestor's hall and the garth as the central axis (such as the ancestral house of Liu family shown in Fig. 1). The principal rooms include one clear-sighted and two dark rooms or one clear-sighted and four dark rooms. The clearsighted room is the ancestors' hall, and the secondary room and the end room are for residence. According to feudal ethics and local customs, the grade of the secondary room is higher than that of the end room, and mostly the elder generation lives there, while the end rooms are for later generations. The wing rooms on both sides are usually with one or two on the left and right sides. There are roughly two kinds of structures for wing rooms: First, the wing room is open to the garth, which can be taken as the side hall, study room, oil manufacturing workshop and other public space. The space is flexible and practical; Second, the wing room is used for living, which is rather clean with strong spatial privacy. The garth is usually of no use, which carries the spirit of ritual symbol, while the front yard in front of the buildings is used for daily drying and grain-sunning ground. Specifically speaking, "Room-wing type" three-section courtyard is small in space suitable for families with a small number of members, and it is the main building form in the initial period of the village.

"Room-building type" courtyard mainly includes buildings of "two-room and two-building", and its plane layout is constituted by "two-room and twowing type" courtyard, left and right long rooms and flower hall. The "two-room and two-building" type is to add subordinate rooms in front of the "Roomwing type" three-section courtyard. The long rooms on both sides are not only for living, but also for the use of kitchen, dining room and farm tool storage. The whole house is in central axial symmetry to be rigorous. As the horizontal direction of the front yard is narrow and long, and the left and right long rooms are also narrow and long in the vertical direction, the three outdoor spaces can constitute the imagery shape of the Chinese character “凹”, making the core part of the central patio more enclosed and the centrality characteristic more prominent. If the house base is large enough, a pool can be set right ahead the wall of the whole house, and the Fetal soil can be set at the back of the principal rooms (such as the Mansion of Senior Official shown in Fig. 2). As both parts are in the semicircle shape, this layout can strength the role of the central patio core part as an entity center and spiritual center. "Room-building type" courtyard is generally the main form developed by villages in the peak period, the building space of which is large with some even taking the "three-room and two-building" layout suitable for larger families.

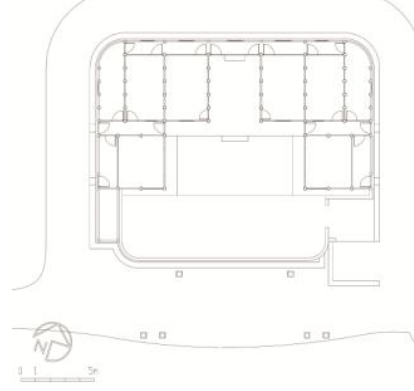

Figure 1 Plane graph of the ancestral house of the Lius

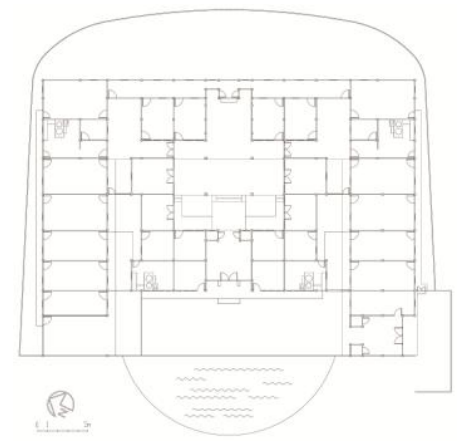

Figure 2 Plane graph of Daifudi

\subsection{Spatial form of streets}

1) Traffic space

Street traffic as a growth context of the traditional villages physical space, which is not only a village spatial form and texture of the main factors in the village, but also an important place for the daily life of the villagers. As for the space formed by the perception of the traditional villages, people tend to also be obtained from the street space. Jishan Village streets and the progressive development of the road system is continuous improvement. Jishan Village from the heyday of the road, the streets can be divided into a total of three levels (Fig. 3).

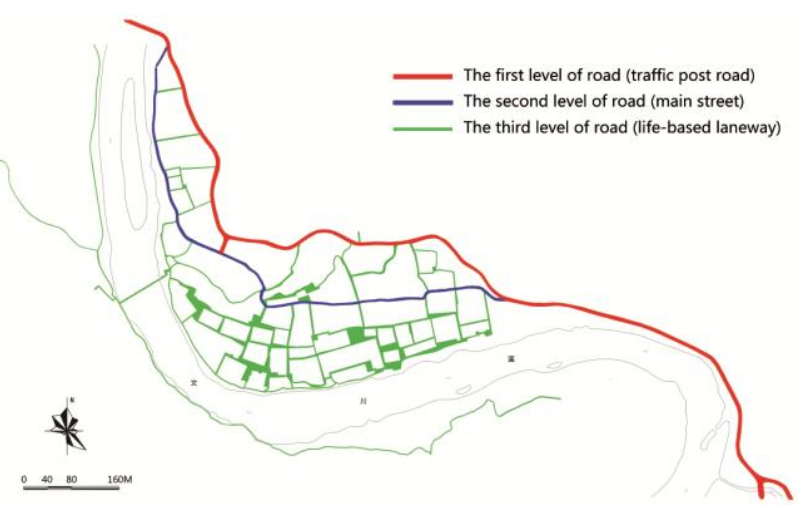

Figure 3 Road grade figure of Jishan Village

The first level belongs to traffic post road. It is a road to enter to the village from the south-east entrance to the northwest of the village. The road was expanded to 5 meters in 1938 to allow the oneway bus driving. Over more than one decade, the traffic post road bridge has extended to the other side of the river and the road has expanded to 7 meters to allow two-way car driving. 
The second level belongs to the main street. It is located in the central position of the village to extend to the east and west. It is the street in daily life of people in the whole village, which passes through the ancestral house, ancestral hall, temple and business street with the integration of spiritual space and public service facilities. It also plays the role as the main place for commercial events and social activities of the village, which makes it the busiest place with the most people. The main street is not only the core to connect the village entrance road and the internal village, it is also the main stem of the village space development vein, which could affect the development mode of the village dramatically as a commander.

The third level belongs to the life-based laneways. It is the most diverse and distinguished laneway space in the village, which connects the main street, the bank space, the residential groups and residences. It is composed of the horizontal and vertical directions. As the plane of Jishan Village is in horizontal shape, there are fewer horizontal lanes, while the number of vertical lanes is large. Due to the land insufficiency, residences are basically built by making full use of the land boundary, thus making the laneway narrow with the widest place no more than 2 meters, some of which are only about 1 meter. The maximized land utilization rate not only leads to the different width and narrowness of the laneway, but also the twists and turns, which leaves a deep impression on the perception and mentality of walkers and intensifies the identify-ability of the laneway. Meanwhile, amplified space is formed in intersections of the laneway sometimes to provide sites for daily communication by villagers. Compared to the main street of the village, the laneway is in a secondary position among the entire village street system. Generally, it is used by adjacent residents and villagers, so it is with certain privacy.

2) Water system space

The water system can play various roles in the village structure, such as drinking, floodwater drainage and firefighting. The water system in Jishan Village is composed of the Jixi River and the ditch mountain spring on Mountain Bei. Meanwhile, the ditch is divided into two small branches in the place close to the end of the village, which finally gathers in Jixi River by combining at the bridgehead of the water end. The width of the ditch passing through the village is mostly around 1.3 meter with the narrowest part only around 0.8 meter. According to the mapping drawing provided by Yong'an Planning Bureau, the elevation of the mountain spring outlet on Mountain Bei is about 203 meters, while that of the ditch on the farm land at the foot of the mountain is about 177 meters. The height for the water outlet combining to Jixi River is 170 meters, and the total level difference is as high as 33 meters. Besides, the total length of the ditch at the outlet part of the bridgehead from the foot of Mountain Bei is about 430 meters, the height difference of which also reaches 7 meters(Fig. 4).

3) Node space

In the area of geometry, node means the connection among lines. The node space of street in Jishan Village is mainly divided into two categories: street intersection space and residential entrance space.

The street intersection space of Jishan Village is presented in various forms, in which, the number of " $T$ " shape intersection is the largest. Meanwhile, most "十" shape intersections have the phenomenon of dislocation with a large number of which in the windmill shape. At the entrance of the buildings, the street will often present different degrees of expanded space (Fig. 5), which often becomes the communication space for people stopped by. This is called the "spontaneous activity space" by Jan Gehl in the book "Life between Buildings[3]."

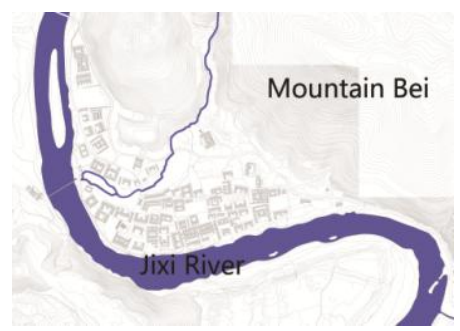

Figure 4 Water system of Jishan Village

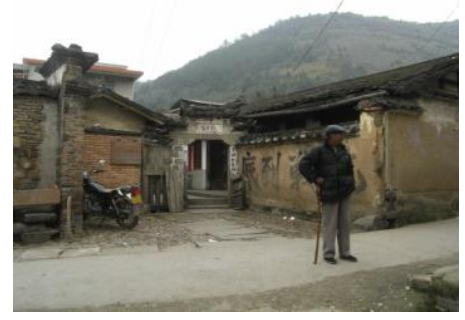

Figure 5 Building entrance space

In fact, the spatial form of notes in the village streets not only includes the street intersection space and the building entrance space, but also is reflected in the street arch space. In Jishan Village, street arch space only shows in the Caipai house which has huge building forms and two groups of completely the same residences as the core. The laneway space entrance between two residences adopts the arch form, thus forming the special spatial element of the village street (Fig. 6).

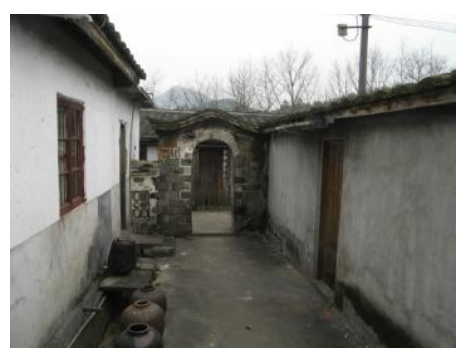

Figure 6 Street archspace 


\subsection{Overall spatial form}

Settlements do not exist in isolation, the surrounding natural landscapes and its affiliated buildings are all integral parts of their overall spatial form. "The overall form of settlements is a critical element to impress people. They are left in the mind of observers and form an overall impression view[4]." (Wang, Y. 2011.) This is consistent with the plan world view of "syncretism between heaven and man" in ancient China. The overall spatial form of Jishan Village integrates with the surrounding landscapes perfectly to sketch out an elaborate village picture of "Landscapes covering thousands of miles" described by Wang Ximeng in Song Dynasty (Fig. 7).

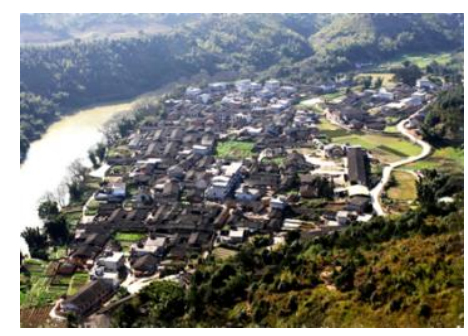

Figure 7 Looking far to the west of Jishan Village

The overall spatial form of Jishan Village mainly includes Jishan Village, Jixi River, Mountain Bei, Jishan Mountain and Baoying Temple in the entrance of the village. In addition to the beautiful and towering natural landscape, the humanistic landscape of Mountain Bei has also been constructed and formed by later generations of the Lius, which seems to be a back yard garden of Jishan Village. The Lius have built an academy, Temple and other pavilions and pagodas on Mountain Bei. Many cliff inscriptions are also left on the mountain, which makes the construction of Jishan Village harmonious with the landscape pattern on a high level. Ancient Chinese people would like to name sceneries and landscapes with "eight major views", which has become a conventional view from natural spot sites to cities or regional well-known sceneries. This is also a kind of historic reflection of humanistic culture. For instance, the "Poem of Eight Major Views on Mountain Bei" and the "Poem of Ten Major Views on Beiling Mountain" made by the Lius have given a high-level literalization to wellknown sceneries on Mountain Bei (Fig. 8), reflecting the unique humanistic connotation of the traditional village Jishan.

As can be seen from the overall spatial form of Jishan Village, the village is located on the valley between the foot of Mountain Bei and Jixi River, which is high in the north and low in the south. The northeast of the village leans to Mountain Bei and the south part faces Nanshanqi. The Jixi River has a winding path of the "几" shape in the village, and the Mountain Bei is like a natural barrier of the village, showing a completely ideal geomancy pattern with "mountains, water and barrier surrounded" (Fig. 9).

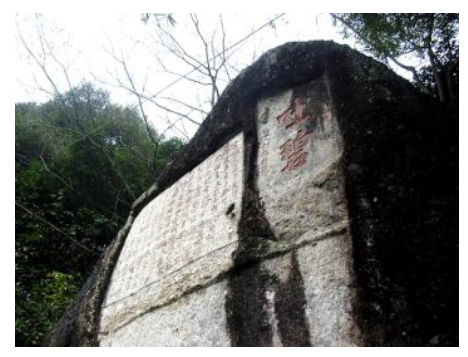

Figure 8 Cliff inscriptions on Mountain Bei

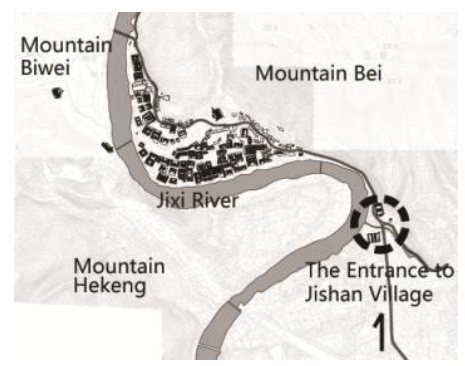

Figure 9 Overall spatial form of Jishan Village

\section{CONCLUSIONS}

Due to the intense urbanization development nowadays, not only the protection and development of traditional villages is in urgent need, but also the new rural construction is imminent. As for the protection and development of traditional villages, physical space constitute is the basis for the village study, and the adherence to preserving the corresponding spatial form is a key link to ensuring the originality of traditional villages. In terms of new rural construction, it is of positive guidance significance by extracting forms from excellent traditional villages to form rules and conduct new rural planning and construction. An analysis for the physical space formation of Jishan Village is conducted by this paper, which not only aims to make an interpretation and explanation about this case, but also hopes to rouse more humanistic concern and care by researchers, urban-rural decision makers and constructors.

\section{REFERENCES}

[1] Li, L. 2003. Rural Settlements: Form Types and Evolution. Nanjing: Southeast University Press.

[2] Spiro, K. 2005. The City Shaped: Urban Patterns and Meanings Through History. (Shan, H, Trans.). Beijing: Industrial Press of Chinese Construction.

[3] Jan,G. 2002. Life between Buildings. (He, K.R, Trans.). Beijing: Industrial Press of Chinese Construction.

[4] Wang,Y. 2011. Learning from Settlements Worldwide. Beijing: Industrial Press of Chinese Construction. 